\title{
CIRI-CIRI KEPRIBADIAN DAN KEPATUTAN SOSIAL SEBAGAI PREDIKTOR SUBJECTIVE WELL-BEING (KESEJAHTERAAN SUBYEKTIF) PADA REMAJA AKHIR
}

\author{
Giyati $^{1}$, Indra Ratna Kusuma Wardani ${ }^{2}$ \\ ${ }^{12}$ Universitas Mercu Buana Yogyakarta \\ ${ }^{2}$ kusumawardanifirdaus@gmail.com
}

\begin{abstract}
Abstrak
Penelitian ini bertujuan untuk mengetahui hubungan antara ciri-ciri kepribadian, kepatutan sosial dengan subjective well-being pada remaja akhir. Sampel penelitian berjumlah 186 remaja laki-laki dan perempuan, usia 18-21 tahun, telah menyelesaikan serangkaian skala subjective well-being, skala ciri-ciri kepribadian Big Five Personality dan skala kepatutan sosial Marlowe Crowne. Analisis regresi berganda digunakan untuk menguji hubungan antara ciri-ciri kepribadian dan kepatutan sosial dengan subjective well-being pada remaja akhir (hipotesis pertama). Analisis korelasi Parsial digunakan untuk menguji hubungan antara ciri-ciri kepribadian dengan subjective well-being pada remaja akhir (hipotesis kedua), dan hubungan antara kepatutan sosial dengan subjective well-being pada remaja akhir (hipotersis ketiga). Hasil analisis data menunjukkan: (1) ada hubungan kuat antara ciri-ciri kepribadian dan kepatutan sosial dengan subjective well-being, dengan koefisien regresi antara ciri-ciri kepribadian dan kepatutan sosial dengan subjective well-being (kepuasan hidup $R_{\mathrm{xy}}=0,449$, afek positif $R_{x y}=0,337$, dan afek negatif $R_{x y}=0,720$ ) dengan nilai $p<0,01$. Hasil analisis varian regresi (kepuasan hidup $\mathrm{F}=7,549$, afek positif $\mathrm{F}=3,828$, dan afek negatif $\mathrm{F}=32,072)$ dengan nilai $\mathrm{p}<0,01$. Prediksi ciri-ciri kepribadian dan kepatutan sosial dengan subjective well-being pada remaja akhir antara $11,4 \%$ hingga 51,8\%. (2) ada hubungan antara ciri-ciri kepribadian dengan subjective well-being, koefisien korelasi antara ciri-ciri kepribadian dan subjective well-being (kepuasan hidup $\mathrm{r}_{\mathrm{xy}}=0,018-0,207$; afek positif $\mathrm{r}_{\mathrm{xy}}=0,011-0,244$; dan afek negatif $\mathrm{r}_{\mathrm{xy}}=0,195-0,438$ ) dengan nilai $\mathrm{p}<0,05$. (3) Ada hubungan antara kepatutan sosial dengan subjective well-being, koefisien korelasi antara kepatutan sosial dan subjective well-being (kepuasan hidup $\mathrm{r}_{\mathrm{xy}}=$ 0,166 ; afek positif $\mathrm{r}_{\mathrm{xy}}=0,175$; dan afek negatif $\left.\mathrm{r}_{\mathrm{xy}}=-0,143\right)$ dengan nilai $\mathrm{p}<0,05$. Kesimpulan: ciri-ciri kepribadian (Big Five Personalty) dan kepatutan sosial (Marlowe Crowne) dapat dijadikan prediktor subjective well-being pada remaja akhir.
\end{abstract}

Kata kunci: Ciri-ciri kepribadian Big Five Personality, kepatutan sosial Marlowe Crowne, subjective wellbeing

\section{CHARACTERISTICS OF PERSONALITY AND SOCIAL PROPRIETY AS A PREDICTOR OF SUBJECTIVE WELL-BEING IN LATE ADOLESCENTS}

\author{
Giyati $^{1}$, Indra Ratna Kusuma Wardani ${ }^{2}$ \\ ${ }^{12}$ Universitas Mercu Buana Yogyakarta \\ ${ }^{2}$ kusumawardanifirdaus@gmail.com
}

\begin{abstract}
This study aims to determine the relationship between personality traits, social propriety with subjective well-being in late adolescents. The study sample of 186 adolescent boys and girls, ages 18-21 years, completed a series of subjective well-being scales, the personality traits scale of the Big Five Personality and the social propriety scale of Marlowe Crowne. Multiple regression analysis was used to examine the relationship between personality traits and social propriety with subjective well-being in late adolescents (first hypothesis). Partial correlation analysis was used to test the relationship between personality traits with subjective well-being in the late adolescents (second hypothesis), and the relationship between social propriety with subjective well-being in the late adolescents (third hypothesis). The results of data analysis showed: (1) there is a strong correlation between personality traits and social propriety with subjective well-being, with a regression coefficient between personality traits and social propriety with subjective well-being ( $R x y=0.449$ life satisfaction, positive affect). $R x y=0.337$, and negative affect $R x y=0.720)$ with a value of $p<0.01$. The results of the regression variance
\end{abstract}


analysis (life satisfaction $F=7.549$, positive affect $F=3.828$, and negative affect $F=32.072$ ) with $p$ values $<0.01$. Predictions of personality traits and social propriety with subjective well-being in late adolescents ranged from $11.4 \%$ to $51.8 \%$. (2) There is a relationship between personality traits and subjective well-being, the correlation coefficient between personality traits and subjective well-being (life satisfaction rxy $=0.018$ 0.207; rxy positive affect $=0.011-0.244$; and negative affect rxy $=0.195-0.438$ ) with a value of $p<0.05$. (3) There is a relationship between social propriety and subjective well-being, the correlation coefficient between social propriety and subjective well-being (life satisfaction rxy $=0.166 ;$ rxy positive affect $=0.175$; and negative affect rxy $=-0.143$ ) with a value of $p<0$, 05. Conclusion: personality traits (Big Five Personality) and social propriety (Marlowe Crowne) can be used as predictors of subjective well-being in late adolescents.

Keywords: personality traits of big five personality, social propriety marlowe crowne, subjective well-being

\section{PENDAHULUAN}

Subjective Well-Being adalah konstruk yang mengevaluasi secara subyektif mengenai kebahagiaan, penga-laman menyenangkan atau pengalaman tidak menyenangkan, serta evaluasi terhadap elemen kehidupan baik dan buruk (Ryan \& Deci, 2001). Menurut Dinner (2000), subjective well-being sebagai kondisi psikologis optimal yang mengandung dimensi kepuasan hidup, kepuasan terhadap bagian yang penting dalam kehidupan, afek positif yang tinggi dan afek negatif yang rendah. Afek positif ditunjukkan dengan kesenangan, cinta, kasih sayang, dan rasa bangga, sedangkan afek negatif ditunjukkan dengan rasa malu, kesedihan, kema-rahan, kebencian, jijik, rasa bersalah, ketakutan, dan kegelisahan. Subjective wellbeing dapat digambarkan sebagai perasaan bahagia individu yang berjangka panjang, perasaan sedih yang minimal dan kepuasan atas kehidupan. Konstruk ini memiliki konsistensi dan stabilitas tinggi dalam berbagai konteks situasi yang diharapkan bagi semua orang, tidak terkecuali pada remaja.

Masa remaja merupakan masa yang sangat baik untuk mengembangkan segala potensi positif yang dimiliki, seperti: bakat, kemampuan, minat dan pengukuhan nilai-nilai hidup. Apabila remaja dapat mengembangkan segala potensi positif yang dimiliki secara optimal, maka remaja akan mudah mencapai subjective well-being (Willis, 2005). Selanjutnya, berhubungan dengan keberhasilan pelaksanaan tugas perkembangan, Havighurst (dalam Willis, 2005) menjelaskan bahwa apabila tugas perkembangan remaja berhasil dilak-sanakan maka akan tercapai subjective well-being bagi remaja, sebaliknya jika gagal maka akan menimbulkan kesulitan pada tahap perkembangan selanjutnya.

Pada masa perkembangan remaja akhir, remaja mulai menjajaki ruang lingkup kehidupan yang luas, seperti: cinta, dunia kerja, dan mulai terlibat dengan lingkungan orang dewasa. Kondisi ini memperlihatkan bahwa proses pematangan diri untuk menjadi orang dewasa telah terjadi pada remaja. Remaja yang secara aktif melakukan pencarian identitas cenderung me-nunjukkan keragu-raguan, kebingungan, gangguan dalam berpikir, bersikap impulsif, dan mengalami konflik dengan orangtua (Santrock, 2002). Kondisi remaja ini dapat dihindari, apabila remaja mempunyai subjective well-being tinggi, karena pada umumnya seseorang dengan subjective well-being tinggi mem-punyai kualitas hidup yang mengagumkan, sehingga lebih mampu mengontrol emosi dan menghadapi berbagai 
peristiwa dalam hidup dengan lebih baik (Diener, 2000). Lain halnya dengan individu yang mempunyai subjective well-being rendah, individu ini akan memandang rendah hidup dan menganggap peristiwa yang terjadi sebagai hal yang tidak menyenangkan sehingga timbul emosi, seperti: kecemasan, depresi, dan kemarahan (Myers \& Diener, 1995).

Pentingnya subjective well-being bagi remaja juga dijelaskan dalam hasil penelitian Day dan Wen (dalam Maulita, 2012) yang mencatat bahwa tingkat subjective well-being pada masa remaja dapat mempengaruhi kesuksesan perkembangan individu dan kualitas hidupnya di masa dewasa. Hasil penelitian ini diperkuat oleh pendapat Suldo (2009); Salami (2010), bahwa kepuasan hidup dan perasaan me-nyenangkan akan membantu remaja untuk dapat belajar dengan maksimal, sehingga keberhasilan akademik dapat tercapai.

Menurut Diener, dkk. (1999), ciri-ciri kepribadian merupakan salah satu prediktor terkuat dan paling konsisten berpengaruh terhadap subjective well-being. Penelitian Lykken \& Tellegen (1996), melaporkan bahwa ciri-ciri kepribadian mempunyai pengaruh jangka pendek sebesar 50\% dan pengaruh jangka panjang sebesar $80 \%$ terhadap subjective well-being. Brajša-Žganec, dkk. (2011) melaporkan bahwa ciri-ciri kepribadian memberikan sumbangan 52\% sebagai prediktor subjective well-being. Hasil ini lebih besar dari hasil penelitian sebelumnya yang dilakukan oleh Chan \& Joseph (2000) yang memberikan sumbangan 30\%, Gutiérrez, dkk. (2005) sebesar 18-20\%, serta Schmutte \& Ryff (1997) sebesar 15-33\%. Berdasarkan hasil penelitian ini, peneliti bermaksud untuk mengangkat ciri-ciri kepribadian sebagai prediktor subjective wellbeing, karena ciri-ciri kepribadian mempunyai konsistensi tinggi dalam mempengaruhi subjective well-being.

Menurut Larsen \& Buss (2002), ciri-ciri kepribadian adalah kumpulan sifat psikologis dalam diri individu yang di-organisasikan, relatif bertahan, mem-pengaruhi interaksi dan adaptasi individu dengan lingkungan, meliputi: lingkungan intrafisik, fisik, dan sosial. Dijelaskan Goldberg (dalam Larsen \& Buss, 2002), model ciri-ciri kepribadian dikenal dengan nama Big Five Personality yang terdiri dari extraversion, agreeableness, conscientiousness, emotional stability, dan intellect atau imagination. Namun Costa dan McCrae (dalam Pervin \& John, 2001; Larsen \& Buss, 2002) me-ngembangkan big five personality dari Goldbert yang terdiri dari: neuroticism, extraversion, openness to experience, agreeableness, dan conscientiousness.

Di dalam model kepribadian Big Five Personality, extraversion dan neuro-tisisme memiliki hubungan paling kuat dan konsisten dengan subjective well-being. Neurotisisme merupakan prediktor penting dari emosi negatif dan kepuasan hidup, sementara extraversion dihubungkan dengan emosi positif dan kepuasan hidup (DeNeve \& Cooper, 1998). BrajšaŽganec, dkk. (2011) dalam penelitiannya melaporkan ciri-ciri ke-pribadian adalah prediktor kuat subjective well-being selama periode 10 tahun. Ciri-ciri kepribadian, seperti: agreeableness dan conscientiousness merangsang pengalaman positif selama 
interaksi sosial dan situasi-situasi pencapaian keberhasilan (prestasi) yang berdampak pada peningkatan subjective well-being. Ciri-ciri kepribadian lainnya yaitu openness to experience dalam hal kecerdasan, memiliki hubungan yang sangat lemah dengan subjective well-being. Dijelaskan Ryan \& Deci (2001) bahwa agreeableness, conscientiousness dan intellect lebih dipengaruhi oleh faktor lingkungan dan peranan budaya, sedangkan extraversion dan neurotisisme lebih dipengaruhi oleh faktor-faktor genetis dalam menjelaskan hubungan antara ciri-ciri kepribadian dengan subjective well-being.

Hubungan ciri-ciri kepribadian dengan subjective well-being dipengaruhi oleh faktor genetik dan lingkungan. Orang-orang yang mempunyai subjective well-being tinggi cenderung mempunyai keterbukaan terhadap pengalaman yang dicirikan oleh kepribadian openness to experience. Keterbukaan terhadap pengalaman mempunyai pengaruh pada afek positif tinggi dan rendah pada afek negatif. Subjective well-being tinggi juga dihubungkan dengan ciri kepribadian extraversion, sebab orang-orang dengan ciri kepribadian extraversion cenderung lebih banyak bergaul sehingga memiliki kesempatan lebih besar untuk menjalin hubungan positif dengan orang lain. Orang-orang extraversion juga mempunyai kepekaan lebih besar terhadap stimulusstimulus positif dari lingkungan sehingga mempunyai reaksi lebih kuat terhadap peristiwa-peristiwa menyenangkan. Subjective well-being rendah dihubungkan dengan ciri kepribadian neurotisisme. Hal ini dikaitkan dengan perilaku neurotik yang berakibat pada ketidakpuasan hidup, cenderung mempunyai emosi negatif tinggi dan emosi positif menurun. Ciri kepribadian agreeableness dan conscientiousness berpengaruh terhadap subjective well-being tinggi. Ciri-ciri kepribadian ini dalam mempengaruhi subjective well-being dipengaruhi imbalan dan keberhasilan dari lingkungan atau masyarakat (Diener, dkk., 1997; Brajša-Žganec, dkk., 2011).

Prediktor subjective well-being lain yang perlu diperhitungkan adalah kepatutan sosial. Berdasarkan hasil penelitian Brajša-Žganec, dkk. (2011) kepatutan sosial (social desirability) merupakan prediktor signifikan kedua komponen subjective well-being. Dijelaskan oleh Diener (2000) bahwa pengukuran subjective well-being dapat dipengaruhi oleh faktor situasional yang sedang berlangsung, suasana hati individu dan bias respon kepatutan sosial. Menurut Penezic \& Ivanov (dalam Brajša-Žganec, dkk., 2011), orang cenderung meningkatkan derajat kepuasan dan kesejahteraan melalui pelaporan diri yang berakibat pada bias respon. Untuk mengontrol bias respon, banyak peneliti menggunakan konstruk kepatutan sosial.

Richman, dkk. (1999) menyatakan bahwa kepatutan sosial (social desirability) merupakan kecenderungan orang merespons dengan caracara yang lebih diinginkan secara sosial di dalam situasi tertentu, sehingga terjadi penipuan respon. Respon yang secara sosial lebih diinginkan seseorang dipercaya meng-arah pada penerimaan atau penghindaran penolakan dari orang lain. Secara singkat kepatutan sosial 
adalah menegaskan yang 'baik' dan menyembunyikan yang 'buruk'.

Kepatutan sosial mempunyai 2 aspek, yaitu: penipuan diri (self-deception) dan manajemen impresi (impression management) (Zickar, dkk., 2004). Peni-puan diri merupakan kecenderungan untuk memberikan diskripsi diri yang jujur tetapi dibesar-besarkan, dilakukan secara tidak sadar, dan merujuk pada gambaran diri yang diinginkan (Paulhus \& Reid, 1991). Secara umum dapat dikatakan penipuan diri adalah bentuk pertahanan diri responden ketika menghadapi situasi yang membahayakan (Widhiarso \& Suhapti, 2007). Manajemen impresi adalah keadaan dimana orang dengan sengaja menampilkan dirinya sesuai dengan norma yang dianggap patut (Judd, 2009). Manajemen impresi merujuk pada upaya meningkatkan daya tarik orang lain (Widhiarso $\&$ Suhapti, 2007).

Hubungan kepatutan sosial dengan subjective well-being dipengaruhi oleh faktor situasional yang sedang ber-langsung, suasana hati dan bias respon kepatutan sosial. Seseorang biasanya melaporkan keadaan diri tidak sesuai dengan keadaan sebenarnya agar diterima oleh lingkungan atau masyarakat, sehingga terjadi bias respon. Bias respon kepatutan sosial tinggi berdampak pada rendahnya subjective wellbeing, sedangkan bias respon kepatutan sosial rendah berdampak pada tingginya subjective well-being (Cuellar, 2005).

Seseorang dengan kepatutan sosial tinggi, mempunyai kecenderungan untuk dapat diterima secara sosial dan meng-hindari penolakan dari orang lain. Seseorang mendapatkan kepuasan hidup dan mempunyai emosi positif apabila mendapatkan penerimaan dan keber-hasilan di dalam lingkungan, namun ketidakpuasan dan emosi negatif tinggi akan didapatkan apabila seeorang tidak mencapai tujuan, impian, dan pengakuan dari lingkungan yang biasanya disebut dengan kegagalan hidup (Brajša-Žganec, dkk., 2011). Menurut Gallagher \& Vella-Brodrick (2008), sebagian besar peneliti subjective well-being tidak memasukkan pengukuran kepatutan sosial, yang ditemukan sangat penting di dalam menjelaskan subjective well-being. Berdasarkan pendapat Gallagher \& Vella-Brodrick (2008) ini, peneliti bermaksud mengangkat kepatutan sosial sebagai prediktor subjective well-being selain ciri-ciri kepribadian, karena kepatutan sosial sangat penting dalam memprediksi subjective well-being.

Sumbangan yang diberikan ciri-ciri kepribadian dan kepatutan sosial dalam memprediksi subjective well-being masingmasing sebesar 52\% dan $13 \%$. Secara bersamasama ciri-ciri kepri-badian dan kepatutan sosial memprediksi subjective well-being sebesar $1 \%$ pada komponen afektif. Hubungan antara ciriciri kepribadian dan kepatutan sosial dengan subjective well-being dijelaskan karena adanya hubungan antara kepri-badian dan kebutuhan akan penerimaan diri yang merupakan salah satu indikator kepatutan sosial hanya akan meng-hubungkan ketiadaan perasaan negatif sebagai karakter individu yang diinginkan secara sosial (Brajša-Žganec, dkk., 2011). Ditegaskan Sandvik, dkk. (dalam BrajšaŽganec, dkk., 2011) bahwa ke-cenderungan merespons dengan menye-nangkan orang lain mempunyai hubungan signifikan dengan 
norma-norma sosial dalam penilaian kesejahteraan subyektif.

Tujuan penelitian ini adalah mengetahui hubungan antara ciri-ciri kepribadian Big Five Personality dan kepatutan sosial (social desirability) sebagai prediktor subjective well-being pada remaja akhir; (2) mengetahui hubungan antara ciri-ciri kepribadian Big Five Personality dengan subjective well-being pada remaja akhir; dan (3) mengetahui hubungan antara kepatutan sosial dengan subjective well-being pada remaja akhir.

\section{METODE}

Penelitian ini melibatkan 186 remaja akhir, usia 18-21 tahun, lokasi penelitian di Fakultas Psikologi Universitas Mercu Buana Yogyakarta. Semua subyek telah menyelesaikan serangkaian skala peng-ukuran yang meliputi Skala Subjective Well-Being, Skala Ciri-ciri, dan Skala Kepatutan Sosial.

Skala Subjective Well-Being, digu-nakan untuk mengungkap sejauh mana tingkat subjective well-being pada remaja akhir. Skala Subjective Well-Being disusun oleh peneliti dengan mengacu pada skala Satisfaction with Life Scale (SWLS) untuk mengukur evaluasi individu mengenai kepuasan hidup dan Scale of Positive and Negative Experince (SPANE) untuk mengukur evaluasi individu mengenai perasaan yang menyenangkan maupun perasaan yang tidak menyenangkan yang sering dirasakan individu dalam hidupnya (Diener, dkk., 1997). Skala Subjective Well-Being memuat 36 aitem yang terdiri dari 12 aitem mengungkap kepuasan hidup, dan 24 aitem mengungkap afek positif dan afek negatif. Uji reliabilitas Skala Subjective Well-Being ditunjukkan dari nilai koefisien Cronbach's Alpha pada kepuasan hidup 0,711; afek positif 0,688; dan afek negatif 0,752. Korelasi butir mengenai validitas pernyataan untuk kepuasan hidup bergerak antara 0,217-0,506, afek positif bergerak antara 0,221-0,474, dan afek negatif bergerak antara 0,228-0,565.

Skala Ciri-ciri Kepribadian digunakan untuk mengungkap sejauh mana ciri kepribadian yang dimiliki remaja akhir. Skala Ciri-ciri Kepribadian yang digu-nakan dalam penelitian ini adalah skala International Personality Item Pool (IPIP) yaitu Skala Big Five Personality pada skala IPIP50 dari Goldber dkk., (2006). Skala Ciri-ciri Kepribadian dari International Personality Item Pool (IPIP) di download dari internet dengan alamat http://ipip.ori.org/. Skala ini mengungkap ciri-ciri kepribadian seseorang, yang terdiri dari 50 aitem untuk pengukuran lima ciri kepribadian, yaitu: extraversion, agreeableness, conscientiousness, neuroticism, dan openness to experience, dengan masingmasing 10 aitem untuk salah satu dari lima ciri kepribadian tersebut. Peneliti menggunakan secara keseluruhan aitem-aitem yang ada di Skala IPIP50 dan mengadaptasi skala ini dalam Bahasa Indonesia dengan cara melakukan alih bahasa sebanyak 3 kali yaitu Bahasa Inggris ke Bahasa Indonesia, dan Bahasa Indonesia ke Bahasa Inggris untuk menjaga validitas isi instrumen. Uji validitas dan reliabilitas dari ciriciri kepribadian Big Five Personality didapatkan koefisien Cronbach's Alpha sebesar 0,78 untuk neuroticism; 0,67 untuk extraversion; 0,71 untuk openness to 
Experience; 0,75 untuk agreeableness; dan 0,68 untuk conscientiousness.

Skala Kepatutan Sosial (Social Desirability). Skala Kepatutan Sosial mengacu pada Skala Kepatutan Sosial Marlowe Crowne bentuk pendek yang terdiri dari 20 aitem yang telah diadopsi dalam penelitian Widhiarso (2011). Pro-ses adaptasi terhadap Skala Kepatutan Sosial Marlowe Crowne oleh Widhiarso (2011) dengan cara menerjemahkan ke dalam Bahasa Indonesia sebanyak dua kali, yaitu dari Bahasa Inggris ke Bahasa Indonesia dan sebaliknya, hal ini dilaku-kan untuk menjaga validitas instrumen. Beberapa pertanyaan dimodifikasi sesuai dengan budaya Indonesia untuk meningkatkan validitas kultural instrumen. Skala Kepatutan Sosial Marlowe Crowne didapatkan hasil nilai koefisien reliabilitas sebesar 0,8201 yang dihitung dengan tehnik estimasi reliabilitas skor komposit.

Data dalam penelitian ini diolah menggunakan analisis regresi untuk melihat hubungan antara ciri-ciri kepribadian dan kepatutan sosial dengan subjective well-being pada remaja akhir (hipotesis pertama), sedangkan analisis korelasi parsial untuk melihat: hubungan antara ciri-ciri kepribadian dengan subjective well-being pada remaja akhir (hipotesis kedua), dan hubungan antara kepatutan sosial dengan subjective well-being pada remaja akhir (hipotesis ketiga).

\section{HASIL DAN PEMBAHASAN}

Tabel 1. Analisis regresi antara ciri kepribadian dan kepatutan sosial dengan subjective well-being pada remaja akhir

\begin{tabular}{lcccc}
\hline \multirow{2}{*}{ Prediktor } & & \multicolumn{3}{c}{ Aspek subjective well-being } \\
\cline { 2 - 5 } & $\begin{array}{c}\text { Kepuasan hidup } \\
\boldsymbol{\beta} \text { (indikasi } \\
\text { prediktor) }\end{array}$ & $\begin{array}{c}\text { Afek positif } \\
\boldsymbol{\beta} \text { (indikasi } \\
\text { prediktor) }\end{array}$ & $\begin{array}{c}\text { Afek negatif } \\
\boldsymbol{\beta} \text { (indikasi } \\
\text { prediktor) }\end{array}$ \\
\hline Ciri-ciri Kepribadian & $\mathrm{R}_{\mathrm{xy}}$ & $0,423^{* *}$ & $0,331^{* *}$ & $0,713^{* *}$ \\
\cline { 2 - 5 } Big Five Personality & $\mathrm{R}^{2}$ & 0,179 & 0,110 & 0,508 \\
\cline { 2 - 5 } Ciri-ciri Kepribadian & $\mathrm{F}$ & $7,826^{* *}$ & $4,439^{* *}$ & $37,166^{* *}$ \\
\cline { 2 - 5 } $\begin{array}{c}\text { Big Five Personality } \\
\text { dan Kepatutan Sosial }\end{array}$ & $\mathrm{R}_{\mathrm{xy}}$ & $0,449^{* *}$ & $0,337^{* *}$ & $0,720^{* *}$ \\
\cline { 2 - 5 } & $\mathrm{R}^{2}$ & 0,202 & 0,114 & 0,518 \\
\hline
\end{tabular}

Keterangan: $* \mathrm{p}<0,05 ; * * \mathrm{p}<0,01$ (signifikan), $\mathrm{R}_{\mathrm{xy}}=$ koefisien regresi, $\mathrm{R}^{2}=$ koefisien determinasi, $\mathrm{F}$ $=$ varian regresi

Masalah serius yang dihadapi remaja akhir berkaitan dengan subjective well-being adalah adanya ketidakpuasan hidup, rendahnya afek positif dan tinggi afek negatif yang berdampak pada penyimpangan, seperti: penyalahgunaan obat-obat terlarang, kesulitan dalam hubungan emosi-sosial, dan adanya interaksi sosial yang buruk (Suldo, 2009). Ada beberapa prediktor yang dapat digunakan untuk memprediksi tingkat subjective well-being pada remaja akhir, salah satunya adalah ciri-ciri kepribadian dan kepatutan sosial (BrajšaŽganec, dkk., 2011).

Tujuan dalam penelitian ini adalah (1) mengetahui hubungan antara ciri-ciri kepribadian Big Five Personality dan kepatutan 
sosial Marlowe Crowne sebagai prediktor subjective well-being pada remaja akhir; (2) mengetahui hubungan antara ciri-ciri kepribadian Big Five Personality dengan subjective well-being pada remaja akhir; dan (3) mengetahui hubungan antara kepatutan sosial Marlowe Crowne dengan subjective well-being pada remaja akhir. Harapan dari penelitian ini adalah dapat memberikan masukan kepada remaja akhir tentang pentingnya mengetahui ciri-ciri kepribadian dan kepatutan sosial sebagai parameter untuk memprediksi subjective well-being.

Tabel 2. Analisis korelasi parsial antara ciri kepribadian dan kepatutan sosial dengan subjective wellbeing pada remaja akhir

\begin{tabular}{|c|c|c|c|c|c|c|c|}
\hline & \multirow{3}{*}{ Variabel } & \multicolumn{6}{|c|}{ Aspek subjective well-being } \\
\hline & & \multicolumn{2}{|c|}{ Kepuasan hidup } & \multicolumn{2}{|c|}{ Afek positif } & \multicolumn{2}{|c|}{ Afek negatif } \\
\hline & & $\mathbf{r}_{\mathrm{xy}}$ & $\mathbf{R}^{2}$ & $\mathbf{r}_{\mathrm{xy}}$ & $\mathbf{R}^{2}$ & $\mathbf{r}_{\mathrm{xy}}$ & $\mathbf{R}^{2}$ \\
\hline \multirow{8}{*}{ 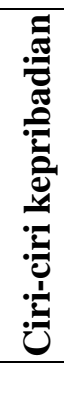 } & Extraversion & $0,150^{*}$ & 0,086 & $0,128 *$ & 0,033 & - & 0,280 \\
\hline & Agreeableness & $-0,018$ & 0,014 & 0,091 & 0,040 & $0,299 * *$ & 0,001 \\
\hline & Conscientiousness & & 0,096 & & 0,075 & $0,195^{*}$ & 0,118 \\
\hline & Neuroticism & $0,207 * *$ & 0,105 & $0,244 * *$ & 0,022 & - & 0,382 \\
\hline & Openness to experience & $-0,142 *$ & 0,034 & $-0,011$ & 0,001 & $0,211 * *$ & 0,088 \\
\hline & & 0,077 & & $-0,082$ & & $0,438 * *$ & \\
\hline & & & & & & $0,208 * *$ & \\
\hline & Kepatutan Sosial & $0,166^{*}$ & 0,062 & 0,175 & 0,017 & $-0,143 *$ & 0,070 \\
\hline
\end{tabular}

$* \mathrm{p}<0,05 ; * * \mathrm{p}<0,01$ (signifikan), $\mathrm{R}_{\mathrm{xy}}=$ Koefisien korelasi, $\mathrm{R}^{2}=$ Koefisien determinasi

Pengujian hubungan antara ciri-ciri kepribadian dan kepatutan sosial dengan subjective well-being dilakukan dengan menghubungkan secara bersama-sama antara ciri-ciri kepribadian Big Five Personality: extraversion, agreeableness, conscientiousness, neuroticism; dan openness to experience dan kepatutan sosial Marlowe Crowne dengan subjective well-being yang terdiri dari: kepuasan hidup, afek positif yang tinggi, dan afek negatif yang rendah. Pengujian hubungan antara ciriciri kepribadian dengan subjective well-being dilakukan dengan menghubungkan ciri-ciri kepribadian Big Five Personality: extraversion, agree-ableness, conscientiousness, neuroticism; dan openness to experience dengan subjective well-being yang terdiri dari: kepuasan hidup, afek positif yang tinggi, dan afek negatif yang rendah. Pengujian hubungan antara kepatutan sosial dengan subjective well-being dilakukan dengan menghubungkan kepatutan sosial Marlowe Crowne dengan subjective well-being yang terdiri dari: kepuasan hidup, afek positif yang tinggi, dan afek negatif yang rendah.

Hasil penelitian menunjukkan bahwa ciriciri kepribadian secara bersama-sama diperhitungan $17,9 \%$ dapat menjelaskan kepuasan hidup, $11 \%$ dapat menjelaskan afek positif, dan 50,8\% dapat menjelas-kan afek negatif pada remaja akhir. Ketika kepatutan sosial sebagai salah satu prediktor subjective well-being dimasuk-kan secara bersama-sama 
dengan ciri-ciri kepribadian ditemukan hasil penelitian 20,2\% dapat menjelaskan kepuasan hidup, 11,4\% dapat menjelaskan afek positif, dan $51,8 \%$ dapat menjelaskan afek negatif pada remaja akhir. Berdasarkan hasil penelitian ini terlihat bahwa penambahan kepatutan sosial pada ciri-ciri kepribadian memberikan tambahan prediksi pada subjective well-being sebesar 2,3\% menjelaskan kepuasan hidup, $0,4 \%$ menjelaskan afek positif dan $1 \%$ menjelaskan afek negatif.

Hasil prediksi ciri-ciri kepribadian untuk subjective well-being dalam penelitian ini lebih rendah dari hasil penelitian ter-dahulu yang dilakukan oleh Brajša-Žganec, dkk. (2011) yaitu antara $17 \%$ hingga $52 \%$, namun hasil penelitian ini lebih tinggi dari penelitian sebelumnya yang dilakukan oleh Chan \& Joseph (2000) yaitu 30\%, Guterrez, dkk.(2005) antara 18\% hingga 20\%, serta Schmutte \& Ryff (1997) antara 15\% hingga $33 \%$, sedangkan hasil penelitian ini prediksi yang diberikan ciri-ciri kepribadian untuk subjective well-being antara $11 \%$ hingga $50,8 \%$. Ketika kepatutan sosial diper-hitungkan sebagai prediktor independen (dimasukkan bersama-sama dengan ciri-ciri kepribadian Big Five Personality), hasil penelitian ini melaporkan hubungan antara ciri-ciri kepribadian dan kepatutan sosial dengan subjective well-being memberikan sumbangan sebesar antara 11,4\% hingga 51,8\%. Menurut Diener, dkk. (1991) kepatutan sosial merupakan karakteristik yang ada pada seseorang yang dapat mempertinggi subjective well-being, bukan merupakan kesalahan respon atau sumber perbedaan keke-liruan atau error terhadap respon skala psikologi.
Menurut Brajša-Žganec, dkk. (2011) hubungan antara ciri-ciri kepribadian dan kepatutan sosial dengan subjective well-being ditunjukkan dengan adanya hubungan antara ciri-ciri kepribadian dengan kebutuhan akan penerimaan diri dari masyarakat (manajemen impresi) hanya akan menghubungkan ketiadaan perasaan negatif pada seseorang. Sandvik, dkk. (dalam Brajša-Žganec, dkk., 2011) menegaskan bahwa kecen-derungan merespons dengan menye-nangkan orang lain (penipuan diri) mempunyai hubungan yang kuat dengan normanorma sosial dalam penilaian subjective wellbeing. Hal ini karena pernyataan bahwa seseorang sejahtera dan bahagia mengandung makna keberhasilan di dalam masyarakat, tetapi saat seseorang menerima ketidak-bahagiaan dan tidak tercapai tujuan dan harapan, hal ini mengandung makna terjadi kegagalan dalam hidup. Asumsi ini yang menegaskan bahwa kepatutan sosial selalu diharapkan seseorang dalam situasi-situasi yang menegangkan dan adanya ketidakbahagian, atau saat adanya perasaan negatif.

Menurut Brajša-Žganec, dkk. (2011), di dalam melaporkan diri, seseorang mem-punyai kecenderungan untuk men-dapatkan dukungan dan pengakuan dari orang lain, sehingga seseorang akan melaporkan keadaan diri tidak sesuai dengan keadaan yang sesungguhnya (terjadi penipuan diri), atau melaporkan diri sesuai dengan norma yang berlaku di masyarakat (manajemen impresi). Hal ini dilakukan seseorang untuk mendapatkan keberhasilan dan kebahagiaan hidupnya. Menurut Pervin \& John (2001), seseorang yang mempunyai kecenderung untuk mendapatkan 
dukungan dan pengakuan dari orang lain dalam mencapai kepuasan hidup merupakan salah satu faktor dari ciri-ciri kepribadian dalam menjelaskan subjective well-being.

Hasil penelitian ini telah membuktikan bahwa ada hubungan antara ciri kepri-badian conscientiousness, extraversion, dan neuroticism dengan subjective well-being pada remaja akhir $(\mathrm{p}<0,05)$, sedangkan ciri kepribadian agree-ableness dan openness to experience tidak ada hubungan dengan subjective well-being pada remaja akhir ( $\mathrm{p}>$ $0,05)$. Hasil penelitian ini mendukung temuantemuan sebelumnya yang dilakukan oleh Schmutte \& Ryff (1997); Chan \& Joseph (2000); Guterrez, dkk. (2005); dan BrajšaŽganec, dkk. (2011), bahwa ada hubungan antara ciri-ciri kepribadian dengan subjective well-being. Di antara kelima ciri-ciri kepribadian tersebut, ciri kepribadian conscientiousness mem-punyai hubungan yang kuat dari ketiga aspek subjective well-being ( $\mathrm{p}<$ 0,01). Arah hubungan yang ditunjukkan ciri kepribadian conscientiousness dengan ketiga aspek subjective well-being adalah hubungan positif tertuju pada kepuasan hidup dan afek positif, hal ini dapat diartikan bahwa skor tinggi pada ciri kepribadian conscientiousness diikuti tingginya kepuasan hidup dan afek positif pada remaja akhir. Hubungan negatif terjadi pada afek negatif, artinya bahwa skor tinggi pada ciri kepribadian conscientiousness diikuti rendahnya afek negatif pada remaja akhir. Hasil penelitian ini mendukung penelitian Gutiérrez, dkk. (2005); Brajša-Žganec, dkk. (2011) yang melaporkan bahwa ada hubungan antara ciri kepribadian conscientiousness dengan ketiga aspek subjective well-being dengan arah hubungan positif pada aspek kepuasan hidup dan afek positif, dan arah hubungan negatif pada aspek afek negatif. Arah hubungan yang telah ditunjukkan ciri kepribadian conscientiousness dengan ketiga aspek subjective wellbeing tersebut mengindikasikan tingginya subjective well-being. Menurut Diener (2000) subjective well-being sebagai kondisi psikologis optimal yang mengandung kepuasan hidup, afek positif tinggi dan afek negatif rendah.

Tingginya subjective well-being pada seseorang yang mempunyai ciri kepri-badian conscientiousness, karena orang-orang tersebut mempunyai kecen-derungan mudah berorganisasi, dapat diandalkan, pekerja keras, disiplin diri, tepat waktu, teliti, rapi, ambisius, dan tekun (Feist \& Feist dalam Widuri, 2010). Remaja akhir yang mempunyai ciri kepribadian conscientiousness mem-punyai kemampuan untuk menginte-grasikan pengalaman masa lalu dan masa sekarang untuk ditransformasikan menjadi konklusi, prediksi, dan rencana untuk masa depan, sehingga remaja mampu mengandaptasikan diri dengan lingkungan sekitarnya (Setiono \& Lili, 2002). Hal ini juga ditegaskan oleh Diener, dkk. (1997), bahwa orang-orang yang mempunyai ciri kepribadian conscientiousness mempunyai kemu-dahan beradaptasi dengan lingkungan. Menurut Brajša-Žganec, dkk. (2011), orang-orang yang mempunyai kemam-puan beradaptasi dengan lingkungan dapat merangsang pengalaman positif selama interaksi sosial, sehingga dapat berdampak pada tingginya subjective wellbeing. 
Ciri kepribadian lainnya yang mempunyai hubungan kuat dengan subjective wellbeing adalah ciri kepribadian neuroticism dan extraversion. Ciri kepri-badian neurotisism sebagai prediktor subjective well-being paling baik dari rendahnya afek negatif dan kepuasan hidup, sedangkan extraversion terbukti sebagai prediktor subjective well-being paling baik dari rendahnya afek negatif, tingginya afek positif dan kepuasan hidup. Hal ini sesuai dengan penelitian terdahulu yang dilakukan oleh Gutierrez dkk. (2005) bahwa neurotisism sebagai prediktor subjective well-being paling baik dari rendahnya afek negatif dan kepuasan hidup, sedangkan extraversion sebagai prediktor subjective well-being paling baik dari tingginya afek positif dan kepuasan hidup.

Diener dkk. (1997) mengemukakah bahwa orang-orang extraversion menga-lami lebih banyak emosi positif, tetapi bukan emosi negatif, dan bahwa seseorang yang mengalami gangguan neurotik memiliki level-level perasaan negatif yang lebih tinggi, tetapi level perasaan positif yang lebih rendah. Shultz, dkk. (dalam Brajša-Žganec, dkk., 2011) menjelaskan bahwa hubungan antara neurotisism dengan subjective well-being, karena adanya perilaku neurotik yang meliputi perasaan cemas, murung, tertekan, dan sedih yang berakibat pada ketidakpuasan. Menurut penelitian ini, penderita neurotik mem-posisikan diri di dalam situasisituasi hidup yang merangsang perasaan negatif dan akibatnya mengalami lebih banyak perasaan-perasaan negatif di dalam hidup.

Menurut Feist \& Feist (dalam Widuri, 2010), seseorang yang mempunyai ciri kepribadian extraversion tinggi cenderung mampu bersosialisasi, aktif, suka ber-bicara, berorientasi pada hubungan dengan manusia, optimis, menyukai kegembiraan, dan setia. Ditegaskan oleh Pervin \& John (2001), bahwa orang-orang extraversion ada kecenderungan untuk membangun intensitas interaksi interpersonal, kebutuhan untuk didukung dan kemampuan untuk berbahagia, sehingga orangorang yang mempunyai ciri-ciri kepribadian extraversion cenderung ramah dan terbuka serta menghabiskan banyak waktu untuk mempertahankan dan menikmati sejumlah besar sosialisasi dalam hidupnya.

Orang-orang extraversion lebih mudah melakukan aktivitas-aktivitas sosial yang membuatnya senang, sehingga mem-punyai level perasaan positif yang lebih tinggi dan rendah pada perasaan negatif, sehingga tercapai kepuasan hidup (Brajša-Žganec, dkk., 2011). Remaja yang melakukan aktivitas-aktivitas sosial dengan menggunakan waktunya dengan kegiatan olah raga, membaca, dan ber-main dengan teman lebih tinggi subjective well-being dibandingkan remaja yang tidak melakukan apaapa (Trzcinsky \& Holst, 2008). Melalui aktivitas-aktivitas sosial remaja cenderung lebih banyak bergaul sehingga memiliki kesempatan yang lebih besar untuk menjalin hubungan positif dengan orang lain, dan lebih banyak memiliki kesempatan untuk mendapatkan umpan balik positif menge-nal dirinya dari orang lain (Bradburn dalam Brajša-Žganec, dkk., 2011). Tentunya aktivitas-aktivitas sosial yang mendorong remaja untuk lebih peka terhadap stimulus-stimulus positif dari lingkungan atau mempunyai reaksi lebih kuat terhadap peristiwa-peristiwa menye-nangkan, 
remaja tersebut mempunyai subjective wellbeing tinggi (Rusting \& Larsen, 1998).

Hubungan kuat antara ciri kepribadian neuroticism dengan ketiga aspek subjective well-being, karena seseorang dengan ciri kepribadian neuroticism tinggi cenderung mudah khawatir, gugup, emosional, tidak aman, tidak cukup (merasa kurang terus), dan suka bersedih (Feist \& Feist dalam Widuri, 2010). Menurut Pervin \& John (2001), seseorang yang memiliki ciri kepribadian neuroticism tinggi mempunyai kecemasan yang berlebih, sifat emosional, dan perasaan tidak aman yang berpengaruh pada pro-ses sosialisasi dengan lingkungan, hal ini tentunya akan menghambat aktivitasnya. Ketidakmampuan untuk mengendalikan kekhawatiran dan kecemasan seseorang yang mempunyai ciri kepribadian neuroticism dapat menjelaskan rendahnya subjective well-being.

Menurut Santrock (2002), pada masa remaja akhir seseorang dalam proses pematangan diri untuk menjadi orang dewasa. Pada masa ini remaja cenderung aktif melakukan pencarian identitas diri yang berdampak pada keragu-raguan, kebingungan, gangguan dalam berpikir, bersifat impulsif, dan mengalami konflik dengan orangtua. Permasalahan-perma-salahan tersebut dapat berdampak pada gangguan neurotik, menurut Shultz, dkk. (dalam Brajša-Žganec, dkk., 2011) bahwa hubungan antara ciri kepribadian neurotisisme dengan subjective well-being berkaitan dengan perilaku neurotik (merasa cemas, murung, tertekan, sedih) yang berakibat pada tingginya emosi negatif dan rendah pada emosi positif, sehingga terjadi ketidakpuasan hidup. Hasil penelitian ini juga telah dibuktikan oleh penelitian terdahulu yang dilakukan Diener, dkk. (1997) bahwa bukti yang memperkuat dari hubungan antara ciri kepribadian neurotisisme dengan subjective well-being ditunjukkan dari seseorang yang mengalami gangguan neurotik yang memiliki level perasaan negatif yang lebih tinggi dan level perasaan positif yang lebih rendah, sehingga tidak ditemukannya kepuasan hidup.

Dua ciri kepribadian lainnya, dalam penelitian ini menunjukkan tidak ada hubungan dengan subjective well-being pada remaja akhir $(\mathrm{p}>0,05)$. Ciri-ciri kepribadian tersebut adalah ciri kepri-badian agreeableness dan openness to experience. Ciri kepribadian agree-ableness dan ciri kepribadian openness to experience ditemukan mempunyai hubungan signifikan dengan subjective well-being hanya pada afek negatif. Hal ini dimungkinkan remaja akhir dengan ciri kepribadian agreeableness tidak men-dapatkan penguat dari faktor lingkungan atau orang lain untuk mendapatkan imbalan atau pencapaian. Asumsi ini ditegaskan oleh Diener, dkk., (1997), bahwa ciri kepribadian agreeablenes dalam menjelaskan subjective well-being, karena didasarkan atas penguat dari faktor lingkungan atau orang lain yaitu melalui imbalan atau pencapaian.

Apabila remaja berada pada ling-kungan yang dapat merangsang penga-laman positif selama interaksi sosial dan dalam situasi keberhasilan, maka subjective well-being yang dimiliki seseorang tinggi (McCrae \& Costa dalam Brajša-Žganec, dkk., 2011). Walaupun, seseorang dengan ciri kepribadian ini dapat mengatasi konflik situasi dengan lebih efektif 
yang mungkin terjadi pada aktivitasnya, namun ling-kungan yang relatif tanpa konflik membuat remaja lebih nyaman dan aman, sehingga dapat memberikan semua kemampuan untuk beraktivitas, yang pada akhirnya terpenuhi kepuasan hidup (Pervin \& John, 2001).

Adapun untuk hubungan antara ciri kepribadian openness to experience dengan subjective well-being hanya ditemukan signifikan pada afek negatif. Hal ini dimungkinkan remaja akhir dengan ciri kepribadian openness to experience tidak mendapatkan umpan balik positif dari lingkungan atas kecerdasan dalam memecahkan masalah. Hasil penelitian ini tidak sesuai dengan hasil penelitian Brajša-Žganec, dkk. (2011), Gutierrez, dkk. (2005), ciri kepribadian openness to experience dengan subjective wellbeing ditemukan signifikan hanya pada afek positif. Menurut Gutierres, dkk. (2005), seseorang dengan ciri kepribadian openness to experience mempunyai emosi positif tinggi, karena adanya umpan balik positif dari lingkungan atas kecerdasan dalam memecahkan masalah secara kreatif dan orisinil, melalui imbalan dan pencapaian inilah emosi positif dapat ditingkatkan.

Santrock (2002), menjelaskan bahwa pada masa remaja akhir seseorang sudah memiliki pola pikir sendiri dalam usaha memecahkan masalah-masalah yang kompleks dan abstrak. Kemampuan ber-pikir para remaja berkembang sedemikian rupa sehingga remaja dengan mudah dapat membayangkan banyak alternatif pemecahan masalah beserta kemungkinan akibat atau hasilnya. Para remaja tidak lagi menerima informasi apa adanya, tetapi remaja akan memproses informasi serta mengadaptasinya dengan pemikirannya sendiri. Namun, menurut Hurlock (1996) adanya ciri remaja yang kadang kurang realistis dengan aspirasinya, sehingga remaja sering mengalami ketidakpuasan hidup karena harapan tidak sesuai dengan keinginan. Remaja sering bersikap menolak terhadap lingkungan, karena sifat idealis yang dimilikinya. Padahal ciri kepribadian openness to experience dalam menjelaskan subjective well-being dibutuhkan imbalan dan pencapaian dari lingkungan. Menurut Gutierres, dkk. (2005), sese-orang yang mempunyai imbalan dan pen-capaian dalam hidupnya karena kecer-dasan yang dimilikinya akan mempunyai emosi positif tinggi emosi positif dan rendah emosi negatif dibanding sese-orang yang mempunyai kecerdasan rendah. Seseorang yang mempunyai kecerdasan merupakan salah satu ciri dari kepribadian openness to experience.

Hasil penelitian ini mendukung hasil penelitian Brajša-Žganec, dkk. (2011), bahwa ada hubungan antara kepatutan sosial dengan subjective well-being $(\mathrm{p}<0,05)$. Menurut Gordon (1987), bahwa seseorang yang mempunyai kepatutan sosial tinggi mengindikasikan seseorang melaporkan dirinya hanya sesuai dengan nilai-nilai kepatutan sosial untuk melindungi gambaran diri di mata orang lain. Individu memilih pelaporan diri yang tidak sesuai dengan keadaan diri, disebabkan pengaruh terhadap peneri-maan dan penghindaran penolakan dari orang lain. Ditegaskan oleh Diener (2000), hubungan antara kepatutan sosial dengan subjective wellbeing dipengaruhi oleh faktor-faktor situasional 
yang sedang berlangsung, suasana hati individu dan khususnya oleh bias respon kepatutan sosial. Crowne \& Marlowe (dalam BrajšaŽganec, dkk., 2011) menyatakan bahwa kepatutan sosial mencerminkan kecende-rungan untuk merespon ke arah peneri-maan atau penghindaran penolakan dari orang lain, sehingga orang akan merasakan kepuasan hidup dan kebahagiaan.

Kepatutan sosial merupakan kecenderungan seseorang untuk melebih-lebihkan sifat dan perilaku yang dinilai patut dan merendahkan sifat dan perilaku yang dinilai tidak patut ketika seseorang melaporkan keadaan dirinya (Klesges, dkk., 2004). Kepatutan sosial yang tinggi dalam penelitian ini dapat dipahami karena pada masa remaja ada kecenderungan remaja untuk menam-pilkan diri palsu untuk dapat diterima dan menghindari penolakan dari lingkungan atau masyarakat (penipuan diri). Remaja juga menggunakan perbandingan sosial untuk mengevaluasi dirinya (manajemen impresi). Kecenderungan remaja untuk melindungi diri sesuai dengan deskripsi diri yang positif merupakan kecende-rungan remaja untuk menggambarkan diri dengan cara yang idealistis (Santrock, 2002).

Brajša-Žganec, dkk. (2011) melapor-kan kepatutan sosial merupakan prediktor kuat dari subjective well-being, karena seseorang akan mendapatkan kepuasan hidup dan mempunyai emosi positif tinggi apabila mendapatkan penerimaan dan keberhasilan di dalam lingkungan atau masyarakat, namun ketidakpuasan hidup dan emosi negatif yang tinggi akan didapatkan apabila seseorang tidak mencapai tujuan, impian, dan pengakuan dari lingkungan atau masyarakat yang biasanya disebut dengan kegagalan hidup.

Kelemahan dalam penelitian ini adalah pengambilan sampel dengan meng-gunakan nonprobabilitas sampling. Tek-nik ini mempunyai kelemahan tidak dapat mengestimasi error yang terjadi, dan hasil penelitian tidak dapat digeneralisasikan secara valid pada populasinya. Masih sedikitnya kerangka teori yang melandasi hubungan antara ciri-ciri kepribadian dan kepatutan sosial dengan subjective well-being, sehingga mempengaruhi pem-bahasan dinamika hubungan antara variabel-variabel yang dilimbatkan dalam penelitian ini

\section{KESIMPULAN}

Berdasarkan hasil penelitian dan pembahasan dapat ditarik beberapa kesimpulan sebagai berikut:

1. Terdapat korelasi yang kuat antara ciriciri kepribadian dan kepatutan sosial secara bersama-sama dengan subjec-tive well-being pada remaja akhir. Ciri kepribadian Big Five Personality diperhitungkan antara $11,0 \%$ hingga $50,8 \%$ memprediksi perbedaan subjec-tive wellbeing. Ketika kepatutan sosial diperhitungkan sebagai prediktor independen (dimasukkan bersama-sama dengan ciri-ciri kepribadian Big Five Personality), sumbangan yang diberikan antara $11,4 \%$ hingga $51,8 \%$. Hubungan antara ciri-ciri kepribadian dan kepatutan sosial dengan subjec-tive well-being ditunjukkan dengan kebutuhan akan penerimaan diri dari masyarakat 
(manajemen impresi) hanya akan menghubungkan keti-adaan perasaan negatif. Kecende-rungan merespons dengan menye-nangkan orang lain (penipuan diri) mempunyai hubungan yang kuat dengan norma-norma sosial secara umum di masyarakat dibanding apa yang dianggap baik oleh masyarakat (manajemen impresi) dalam penilaian subjective well-being. Ciri kepribadian extraversion mempunyai kecende-rungan untuk mendapatkan dukungan dan pengakuan dari orang lain dalam mencapai kepuasan hidup. Di dalam pelaporan diri, seseorang yang mempunyai kecenderungan untuk mendapatkan dukungan dan pengakuan dari orang lain, akan melaporkan keadaan diri tidak sesuai dengan keadaan diri yang sesungguhnya (terjadi penipuan diri), atau melaporkan diri sesuai dengan norma yang berlaku di masyarakat (manajemen impresi). Subjective well-being pada seseorang yang mempunyai ciri kepribadian extraversion akan meningkat dengan adanya dukungan dan pengakuan dari orang lain (kepatutan sosial), namun berdasarkan skala kepatutan sosial pelaporan diri dari seseorang yang mempunyai ciri kepribadian extra-version akan menurunkan subjective well-being, karena adanya bias respon dengan pelaporan diri yang tidak sesuai dengan keadaan diri.

2. Ada hubungan antara ciri-ciri kepribadian dengan subjective well-being. Ciri kepribadian extraversion dan neuroticism memiliki hubungan paling kuat dan konsisten dengan subjective well-being. Ciri kepribadian neuro-ticism mempunyai hubungan kuat pa-da tingginya afek negatif $\left(\mathrm{r}_{\mathrm{xy}}=0,438\right)$ dan rendahnya kepuasan hidup $\left(\mathrm{r}_{\mathrm{xy}}=-0,142\right)$, sementara ciri kepribadian extraversion mempunyai hubungan kuat pada rendahnya afek negatif $\left(\mathrm{r}_{\mathrm{xy}}=-0,299\right)$ dan tingginya kepuasan hidup $\quad\left(\mathrm{r}_{\mathrm{xy}}=0,150\right)$ dengan nilai $\mathrm{p}<0,01$. Ciri kepribadian conscientiousness mem-punyai hubungan kuat pada ketiga aspek subjective wellbeing $(\mathrm{p}<0,05)$, sedangkan ciri kepribadian agree-ableness, dan openness to experience hanya dapat menjelaskan afek negatif $(p>0,05)$. Kedua ciri kepribadian ini sebenarnya dapat merangsang penga-laman positif selama interaksi sosial dan situasi-situasi pencapaian keber-hasilan sehingga dapat menjelaskan subjective well-being. Ciriciri kepri-badian agreeableness, conscien-tiousness, dan openness to experience lebih dipengaruhi oleh faktor ling-kungan dan budaya, sedangkan extraversion dan neuroticism lebih dipengaruhi oleh faktor genetik dalam menjelaskan subjective well-being pada remaja akhir. Hubungan antara ciri-ciri kepribadian dengan subjective well-being dijelaskan dijelaskan dari hasil koefisien korelasi antara ciri-ciri kepribadian dan subjective well-being (kepuasan hidup $\mathrm{r}_{\mathrm{xy}}$ $=0,018-0,207$; afek positif $r_{\mathrm{xy}}=0,011-$ 0,244; dan afek negatif $r_{x y}=0,195-0,438$ ) dengan nilai $\mathrm{p}<0,05$. 
3. Ada hubungan antara kepatutan sosial dengan subjective well-being. Hubung-an antara kepatutan sosial dengan subjective well-being dipengaruhi oleh faktor-faktor situasional yang sedang berlangsung, suasana hati individu dan khususnya oleh bias respon kepatutan sosial. Kepatutan sosial mencerminkan kecenderungan untuk merespon ke arah penerimaan atau penghindaran penolakan dari orang lain. Seseorang yang mempunyai kepatuan sosial tinggi cenderung menampakkan kepuasan hidup dan emosi positif tinggi, serta menurunkan emosi negatif. Kepatutan sosial mempunyai hubungan kuat pada rendahnya afek negatif $\left(\mathrm{r}_{\mathrm{xy}}=-\right.$ $0,143)$ dan tingginya kepuasan hidup $\left(\mathrm{r}_{\mathrm{xy}}\right.$ $=0,166)$, dengan nilai $\mathrm{p}<0,05$.

\section{SARAN}

1. Bagi orangtua. Disarankan kepada orangtua untuk memperhatikan ciri-ciri kepribadian dan kepatutan sosial anakanaknya, karena ciri-ciri kepri-badian dan kepatutan sosial dapat dijadikan prediktor subjective well-beingpada masa remaja akhir, se-hingga peningkatan subjective well-being pada remaja dapat diupayakan sejak dini.

2. Bagi remaja. Untuk memperhatikan kelemahan-kelemahan dan kelebihankelebihan dari ciri-ciri kepribadian dan kepatutan sosial yang melekat pada diri remaja, sehingga remaja lebih mampu mengusahakan subjective well-being.

3. Bagi peneliti selanjutnya. Untuk penelitian selanjutnya yang berminat untuk mengangkat tema yang sama diha-rapkan mempertimbangkan variabel-variabel lain yang diperkirakan mem-pengaruhi subjective well-being pada remaja akhir. Hal lain yang perlu diperhatikan adalah penggunaan data tambahan seperti observasi dan wawancara agar hasil yang didapat lebih mendalam dan paripurna, karena tidak semua hal dapat diungkap menggunakan skala penelitian.

\section{DAFTAR PUSTAKA}

Brajša-Žganec, A., Ivanovic, D., \& Lipovcan, L.K.( 2011). Personality Traits and Social Desirability as Predictors of Subjective Well-Being. Psihologijske Teme, 20(2), 261-276.

Chan, R., \& Joseph, S. (2000). Dimen-sions of personality, domains of aspiration, and subjective well-being. Personality and Individual Differences, 28, 347-354.

Compton, W.C. (2005). Introduction to Positive Psychology. New York: Thomson Wadsworth.

Cuellar, R. (2005). The Validation of the anger implicit association test. Disser-tation. Texas: A \& M University.

DeNeve, K.M., \& Cooper, H. (1998). The happy personality: A meta-analysis of 137 personality traits and subjective wellbeing. Psychological Bulletin, 124(2), 197-229.

Diener, E. (2000). Subjective well-being: The science of happiness and a proposal for a national indeks. American Psychologist, 55(1), 34-43.

Diener, E., Suh, E.M., \& Oishi, S. (1997). Recent findings on subjective well-being. Indian Journal of Clinical Psychology, 24(1), 25-41.

Diener, E., Suh, E.M., Lucas, R.E., \& Smith, H.L. (1999). Subjective well-being: Three decades of progress. Psychological Bulletin, 125, 276-302. 
Fujita, F. (1991). An investigation of the relation between extraversion, neuroticism, positiveaffect, and negative affect. MS thesis. Univ.Ill., UrbanaChampaign.

Goldberg, L.R., Johnson, J.A., Eber, H.W., Hogan, R., Ashton, M.C., Cloninger, C.R., \& Gough, H.G. (2006). The international personality item pool and the future of public-domain personality measures. Journal of Research in Personality, 40, 84-96.

Gordon, R. (1987). Social desirability bias: a demonstration and technique for its reduction. Journal Teaching of Psychology, 14(1),

Gutiérrez, J.L.G., Jiménez, B.M., Hernández, E.G. \& Puente, C.P. (2005). Personality and subjective well-being: big five correlates and demographic variables. Personality and Individual Differences, 7(38), 1561-1569.

Judd, M. (2009). Religious orientation, context effects, and socially desirable responding. Thesis. Marietta College.

Klesges, L., Baranowski, T., Beech, B., Cullen, K., Murray, D., Rochon, J., \& Pratt, C. (2004). Social desirability bias in selfreported dietary, physical activity and weight concerns measures in 8- to 10 year-old African-American girls: results from the Girls health Enrichment Multisite Studies (GEMS). Preventive Medicine, 38, 78-87.

Larsen, R.J. \& Buss, D.M. (2002). Personality psychology: domain of knowledge about human nature. New York: McGraw Hill.

Lykken, D., \& Tellegen, A. (1996). Happiness is a stochastic pnenomenon. Psychol. Sci. 7, 186-89.

Maulita, E.S. (2012). Pengaruh pola asuh autoritatif dan konsep diri terhadap subjective well-being pada remaja. Tesis (tidak dipublikasikan). Universitas Gadjah Mada, Yogyakarta.

Myers, D.G., \& Diener, E. (1995). Who is happy? Psychological Science, 6(1), 1019.
Paulhus, D.L., \& Reid, D.B. (1991). Enhancement and denial in socially desirable responding. Journal of Personality and Social Psychology, 60, 307-317.

Pervin, L.A., \& John, O.P. (2001). Personality; theory and reasearch. $8^{\text {ed }}$. New York: John Wiley \& Sons, Inc.

Richman, W.L., Weisband, S., Kiesler, S., \& Drasgow, F. (1999). A meta-analytic study of social desirability distortion in computer-administered questionnaires, traditional questionnaires and interviews. Journal of Applied Psychology, 84,754775 .

Rusting, C.L., \& Larsen, R.J. (1998). Extraversion, neuroticism, and susceptibility to positiveand negative affect: a test of two theoreticalmodels. Personal. Individ. Differ, 22, 607-12.

Ryan, R.M., \& Deci, E.L. (2001). On happiness and human potentials: A review of research on hedonic and eudaimonic well-being. Annual Review of Psychology, 52,141-166.

Salami, S.O. (2010). Emotional intelligence, self-efficacy, psuchological well-being and student's attitudes: implications for quality education. European Journal of Educational Studies, 2(3), 247-257.

Santrock, John W. (2002), Live - Span Developmen, Alih Bahasa: Achmad Chusairi, Perkembangan Masa Hidup, Edisi Ke 5, Jilid 1-2, Jakarta: Penerbit Erlangga.

Schmutte, P.S., \& Ryff, D.C. (1997). Personality and well-being: what is the connection? Journal of Personality and Social Psychology, 73, 549-559.

Setiono., \& Lili H. (2002). Beberapa Permasalahan Remaja, dalam http://www.e-psikologi.com.

Suldo, S.M. (2009). Parent-child relationship. In R. Gilman, E.S., Huebner, dan M.J. Furlong. Handbook of Positive Psychology in School. Taylor dan Francis Routledge, New York, p. 245-256. 
Trzcinski, E., \& Holst, E. (2008). Subjective well-being among young people in transition to adulthood. Social Indicators Research, 87(1), 83-109.

Widhiarso, W. (2011). Evaluasi properti psikometris skala kepatutan sosial adaptasi dari Marlowe-Crowne Social Desirability Scale. Insani, 13(03), 138148.

Widhiarso, W. (2012). Mendeteksi respon error pada skala psikologi melalui respons kepatutan sosial. Jurnal Penelitian, Fakultas Psikologi Universitas Gadjah Mada Yogyakarta, p. 1-13.

Widhiarso, W., \& Suhapti, R. (2007). Eksplorasi karakteristik aitem skala psikologis yang rentan terhadap tipuan respon. Yogyakarta: Fakultas Psikologi Universitas Gadjah Mada.

Widuri, E.L. (2010). Kepribadian big five dan strategi regulasi emosi ibu anak ADHD (Attention Deficit Hyperactivity Disorder). Humanitas, 7(2), 123-137.

Willis, Sofyan S. (2005). Remaja dan masalahnya mengupas berbagai bentuk kenakalan remaja seperti narkoba, freesex dan pemecahannya. Bandung: $\mathrm{CV}$ Alfabeta.

Zickar, M.J, Gibby, R.E., \& Robie, C. (2004). Uncovering faking samples in applicant, incumbent, and experimental data sets: an application of mixed-model item response theory. Organizational Research Methods, 7(2), 168-190. 